\title{
Pengaruh Metode Bernyanyi terhadap Kemampuan Mengingat Huruf dan Angka pada Anak Usia Dini
}

\author{
Kamtini' ${ }^{1}$ Fahmi Agustina Sitompul ${ }^{2}$ \\ Pendidikan Guru Pendidikan Anak Usia Dini, Universitas Negeri Medan \\ DOI: $10.31004 /$ obsesi.v4i1.295
}

\begin{abstract}
Abstrak
Permasalahan dalam penelitian ini adalah rendahnya kemampuan anak dalam kemampuan mengingat huruf dan angka. Penelitian ini bertujuan untuk mengetahui pengaruh metode bernyanyi terhadap kemampuan mengingat huruf dan angka anak usia 5-6 tahun.Penelitian ini adalah penelitian eksperimen dengan jumlah populasi penelitian 54 anak dan menggunakan teknik pengambilan sampel random sampling, Kelas eksperimen 15 orang anak dengan pembelajaran menggunakan metode bernyanyi, dan kelas kontrol 15 orang anak dengan pembelajaran menggunakan metode ceramah. Hasil penelitian menunjukkan ada pengaruh yang signifikan dari metode bernyanyi terhadap kemampuan mengingat huruf dan angka anak usia 5-6 tahun dengan nilai rata-rata 7,2 standar deviasi 1,42 dengan nilai tertinggi 9 dan nilai terendah 5 .
\end{abstract}

Kata Kunci : Metode Bernyanyi, Kemampuan Mengingat Huruf dan Angka

\begin{abstract}
The problem in this study was the low ability of children in the ability to memorise words. This research aimed to determine the influence of the method of singing to the ability of memorising letters and numbersfor children age 5-6 years. This research was experimental research with the number of population is 54 children and using sampling technique random sampling. For an experimental class of 15 children with learning using the singing method, and a control class of 15 children with learning using the lecturing method. The results showed there were significant influence of the method of singing to the ability in memorising letters and numbers for children age 5-6 years with an average value of 7.2 standard deviations 1.42 with the highest value of 9 and the lowest value of 5 .
\end{abstract}

Keywords: Singing Methods, Remembering Letters and Numbers Abilities

Copyright (c) 2019 Kamtini, Fahmi Agustina Sitompul

$\triangle$ Corresponding author :

Email Address : kamtini@unimed.ac.id (Medan, Indonesia )

Received 1 October 2019, Accepted 17 October 2019, Published 26 October 2019

\section{PENDAHULUAN}

Masa usia dini adalah masa yang sangat menentukan bagi perkembangan dan pertumbuhan anak karena merupakan masa peka dalam kehidupan anak. Pada masa ini merupakan masa untuk meletakkan dasar pertama dalam mengembangkan kemampuan fisik, kognitif, bahasa, sosial emosional, konsep diri, disiplin, kemandirian, seni, moral, dan nilai-nilai agama. 
Dalam Undang-Undang Nomor 20 Tahun 2003 tentang Sistem Pendidikan Nasional Pasal 1 butir 14 menyatakan bahwa Pendidikan Anak Usia Dini (PAUD) adalah suatu upaya pembinaan yang ditujukan kepada anak sejak dini sampai dengan usia enam tahun yang dilakukan melalui pemberian rangsangan pendidikan untuk membantu pertumbuhan dan perkembangan jasmani dan rohani agar anak memilki kesiapan dalam memasuki pendidikan lebih lanjut.

Piaget (Santrock, 2007: 243) menekankan bahwa anak-anak secara aktif membangun dunia-dunia kognitif mereka sendiri, informasi dari lingkungan tidak begitu saja dituangkan kedalam pikiran-pikiran mereka. Kemampuan mengingat merupakan kemampuan kognitif paling dasar, daya ingat merupakan kunci dalam setiap pelajaran. Menurut Irham (2013: 34) memori atau ingatan merupakan aktivitas menerima, menyimpan, dan mereproduksi kembali kesan, pengetahuan sebagai hasil belajar dan pengalaman.

Walgito (2004: 144) mengemukakan bahwa ingatan merupakan kemampuan psikis untuk memasukkan (learning), menyimpan (retention), dan menimbulkan kembali (remembering) hal- hal yang lampau. Ketika mencoba untuk menarik informasi dari ingatan, anak-anak prasekolah melakukan pengenalan, mengidentifikasi sesuatu yang ditemukan sebelumnya, kemudian mengingat mereproduksi informasi dari memori.

Jahja (2011: 186) mengukur memori jangka pendek anak dapat menyimpan informasi selama 15 hingga 30 detik dan memori jangka panjan anak usia empat tahun mencapai $75 \%$ dari waktunya dalam merekognisi gambar yang telah diperlihatkan satu minggu sebelumnya.

Menurut Papalia (2008: 349) memori atau ingatan anak terus meningkat pada usia antara 5 sampai 8 tahun, memori setelah masa tersebut mungkin dapat diingat setelah dua puluh, tiga puluh, atau empat puluh tahun kemudian. Hal tersebut menjelaskan bahwa fase kemampuan mengingat pada usia 5-6 tahun penting untuk dioptimalkan agar mendukung aspek perkembangan kognitifnya.

Menurut Beaty (2013: 277) menjelaskan pembelajaran kognitif anak usia dini antara lain : (1) memilih objek berdasarkan bentuk, warna; (2) mengelompokkan objek berdasarkan ukuran; (3) menempatkan objek dalam urutan; (4) menghitung sambil menghafal.

Mutiah (2012: 161) menjelaskan bahwa pembelajaran huruf dan angka merupakan pembelajaran yang sangat penting bagi keberhasilan anak dimasa yang akan datang.

Berdasarkan survey pendahuluan yang dilakukan di TK Aisyiyah Bustanul Athfal O6 Bromo Medan, sebagian besar anak kelompok TK B dalam perkembangan kognitif terutama kemampuan mengingat masih tergolong rendah. Hal tersebut diperoleh dari 28 anak yang belum berkembang terlihat dari anak masih belum mengingat huruf, angka atau bilangan yang diajarkan oleh guru secara optimal, sedangkan 26 anak yang berkembang sesuai harapan terlihat dari anak mampu mengenal huruf dan kata.

Kemudian metode pembelajaran yang digunakan guru kurang bervariasi hanya metode bercakap-cakap (ceramah) dan metode pemberian tugas saja yang tidak menarik perhatian anak sehingga guru sering mengalami kendala saat melakukan proses belajar mengajar disekolah. Hal ini dipicu oleh kegiatan bermain sambil belajar dengan menggunakan metode bernyanyi sangat jarang dilakukan dalam pembelajaran untuk mendukung kemampuan mengingat anak dikelas.

Suryosubroto (2009: 155) menjelaskan metode ceramah sebagai metode mengajar melalui penerangan dan penuturan secara lisan oleh guru terhadap kelasnya. Fadlillah (2012: 164) mengatakan metode ceramah memiliki kelemahan seperti siswa kurang aktif karena cenderung hanya mendengarkan.

Honig dalam Latif (2014: 112) mengemukakan bahwa bernyanyi memiliki banyak manfaat untuk praktik pendidikan anak dan pengembangan pribadi anak secara luas, karena : (1) benyanyi bersifat menyenangkan; (2) benyanyi dapat dipakai untuk mengatasi kecemasan; (3) bernyanyi merupakan media untuk mengespresikan perasaan; (4) bernyanyi dapat membantu membangun rasa percaya diri anak; (5) bernyanyi dapat membantu daya 
ingat anak; (6) bernyanyi dapat mengembangkan rasa humor; (7) bernyanyi dapat mengembangkan keterampilan berpikir dan kemampuan motorik anak; dan (8) bernyanyi dapat meningkatkan keeratan dalam sebuah kelompok.

Wijanarko (2005: 47) menjelaskan sebuah konsep akan lebih mudah ditanamkan lewat lagu karena diucapkan berkali-kali bahkan dihafalkan sehingga dengan bernyanyi anak tanpa sadar dilatih daya ingatnya dan dengan menghafal lirik lagu tersebut, kecerdasannya dipacu (ritme, birama, dan irama bisa menjadi terapi faraf-saraf otak) lewat hal yang disukai.

Metode bernyanyi memiliki beberapa kelebihan dan kekurangan saat penggunaannya dalam pembelajaran.

Menurut Muliawan (2016: 214) mengemukakan kelebihan penggunaan metode bernyanyi dalam pembelajaran anak usia dini antara lain : (1) mudah, murah, sederhana dan menyenangkan; (2) pengetahuan/ pesan-pesan moral yang disampaikan dapat melekat dalam ingatan anak dalam jangka waktu yang cukup lama; (3) untuk jenis lagu tertentu dapat menumbuhkan semangat dan gairah hidup, jiwa patriotisme, dan hasrat pengorbanan yang besar.

Widyaastuti (2016: 70) menyarankan agar pemilihan lagu anak di PAUD memenuhi kriteria yang sesuai kebutuhan anak seperti lirik sederhana dan mudah dipahami anak dan nada yang menarik dan tidak terlalu sulit.

Adapun penelitian yang relevan yang dapat dijadikan dasar melaksanakan penelitian lebih lanjut adalah penelitian dari Arifin (2015) PG PAUD Universitas Sebelas Maret yang berjudul "Upaya Meningkatkan Kemampuan Mengingat Urutan Kata Melalui Metode Bernyanyi. Hasil penelitian mengungkapkan bahwa metode bernyanyi dapat meningkatkan keterampilan mengurutkan kata Dengan metode bernyanyi, maka kemampuan mengingat huruf dan angka anak dapat meningkat, dibandingkan apabila metode yang digunakan pada anak hanya dengan menggunakan metode ceramah..

\section{METODOLOGI}

Penelitian dilakukan menggunakan jenis penelitian eksperimen.Populasi dalam penelitian ini berjumlah 54 anak usia 5-6 tahun. Kemudian sampel dilakukan secara random, kelas eksperimen dan kelas kontrol masing-masing berjumlah 15 anak.

Penelitian menggunakan analisis deskriptif. Kegiatan analisis diawali dari mentabulasi data hasil observasi, kemudian disajikan dalam bentuk daftar distribusi frekuensi beserta grafiknya.Selanjutnya melakukan perhitungan dengan statistik inferensial untuk menguji hipotesis dengan analisis Uji-T. , yang terlebih dahulu dilakukan Uji persyaratan analisis yaitu uji Normalitas dengan Liliefors dan Uji homogenitas dengan Uji-F.

Kriteria pengujian hipotesis adalah Ho diterima Jika $t_{\text {hitung }}>t_{\text {tabel }}$ dengan $d k=\left(n_{1}+n_{2-}\right.$ 2 ) dengan peluang $(1-a)$ dan taraf nyata $a=0,05$. Dan tolak Ho jika t mempunyai hargaharga lainnya.

Ho diterima apabila harga $t_{\text {hitung }}<t_{\text {tabel }}$ dan Ha ditolak

Ho diterima apabila hrga $t_{\text {hitung }}>t_{\text {tabel }}$ dan Ho ditolak

\section{HASIL DAN PEMBAHASAN}

Hasil observasi kemampuan mengingat anak dalam kelas eksperimen dipaparkan melalui skor nilai observasi kemampuan mengingat melalui grafik histogram sebagai berikut: 


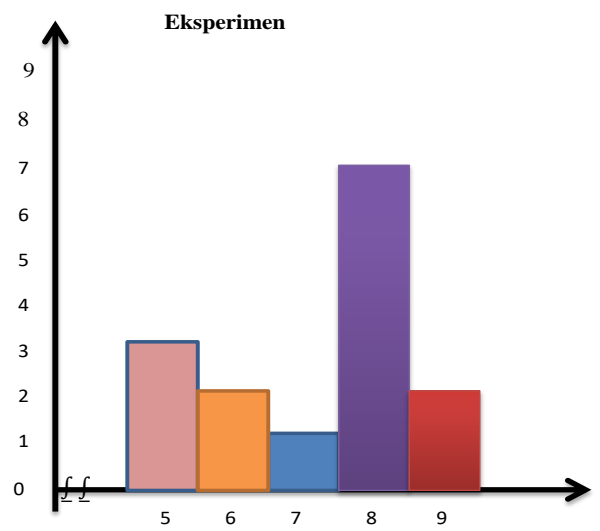

\section{Gambar 1 Hasil observasi kemampuan mengingat anak dalam kelas eksperimen}

Data diatas menunjukkan bahwa kemampuan mengingat huruf dan angka pada anak kelas eksperimen memperoleh rata-rata 7,2 standar deviasi 1,42 dengan nilai tertinggi 9 dan nilai terendah 5 , sehingga dapat disimpulkan kemampuan mengingat huruf dan angkaanak pada kelas eksperimen tergolong dalam kategori berkembang sangat baik

Hasil observasi kemampuan mengingat huruf dan angka anak dalam kelas kontroldipaparkan melalui skor nilai observasi kemampuan mengingat melalui grafik histogram sebagai berikut :

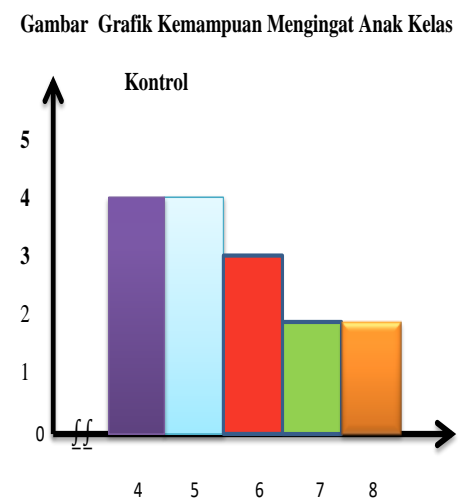

Gambar 1 Hasil observasi kemampuan mengingat anak dalam kelas kontrol

Berdasarkan data hasil observasi kelas eksperimen dan kelas kontrol diatas, maka dijelaskan bahwa kelas eksperimen memiliki nilai terendah 5, nilai tertinggi 9 sedangkan kelas kontrol memiliki nilai terendah 4 dan nilai tertinggi 8 serta nilai rata-rata yang lebih tinggi dibandingkan kelas kontrol. Hal ini menunjukkan bahwa kemampuan mengingat huruf dan angkapada anak kelas eksperimen lebih baik dibandingkan anak kelas kontrol. Hasil pelaksanaan metode bernyanyi yang dilakukan dilkelas eksperimen sangat berpengaruh pada kemampuan mengingat anak, karena terlihat jelas saat anak sangat antusias menyanyikan lagu yang di bawakan oleh guru dan anak dengan mudah mengingat bilangan, benda berdasarkan warna dan macam lambang huruf vokal, konsonan dan hijaiyah. Sedangkan dengan metode ceramah dikelas kontrol kurang memuaskan. Hal ini terlihat saat anak mengingat bilangan, benda berdasarkan warna dan macam lambang huruf vokal, konsonan dan hijaiyah terlihat anak belum menyebutkan dengan tepat serta hanya mengikut apa yang disebutkan temannya.Kemudian berdasarkan hasil pengujian hipotesis penenelitian diperoleh nilai $\mathrm{T}_{\text {hitung }}=3,766$ dibandingkan dengan nilai $\mathrm{T}_{\text {tabel }}=1,701$ dengan $\left(d k=\left(n_{1}+n_{2}\right)-2=28\right.$ dan taraf $\left.\alpha=0,05\right)$. Sehingga $T_{\text {hitung }} 3,766>T_{\text {tabel }}=1,701$, maka $H_{0}$ ditolak dan Ha diterima, sehingga dapat dinyatakan "Ada pengaruh yang signifikan dari metode bernyanyi terhadap kemampuan mengingat huruf dan angka anak usia 5-6 tahun di TK Aisyiyah Bustanul Athfal 06 Bromo Medan 
Berdasarkan hasil pengujian hipotesis penelitian dapat disimpulkan bahwa metode bernyanyi memilki pengaruh yang signifikan terhadap kemampuan mengingat. Penggunaan metode bernyanyi membuat kemampuan mengingat huruf dan angka semakin meningkat, hal ini sesuai dengan pendapat Honig bahwa metode bernyanyi bermanfaat dalam praktik pendidikan karena bernyanyi bersifat menyenangkan dan bernyanyi dapat membantu daya ingat anak.

Hasil penelitian ini juga sejalan dengan hasil penelitian dari Arifin (2015) yang mengungkapkan bahwa metode bernyanyi dapat meningkatkan keterampilan mengurutkan kata. Dengan metode bernyanyi, maka kemampuan mengingat huruf dan angka anak dapat meningkat.

\section{SIMPULAN}

Berdasarkan hasil penelitian yang telah dilakukan maka dapat diambil kesimpulan ada pengaruh yang signifikan metode bernyanyi terhadap kemampuan mengingat huruf dan angka anak usia 5-6 tahun. Hal ini ditunjukkan oleh hasil uji hipotesis $t_{\text {hitung }}>t_{\text {tabel }}(3,766$ $>1,701$ ) pada taraf $a=0,05$, menunjukkan bahwa hipotesis $\mathrm{H} 0$ ditolak dan Ha diterima. Pelaksanaan metode bernyanyi memberikan pengaruh yang signifikan terhadap kemampuan mengingat huruf dan angka dibandingkan dengan metode ceramah. Hal ini ditunjukkan dari hasil kemampuan mengingat huruf dan angka anak pada kelas eksperimen menunjukkan nilai rata-rata lebih tinggi yaitu sebesar 7,2 di bandingkan kelas kontrol yaitu sebesar 5,6, tergolong dalam kategori berkembang sangat baik .

\section{DAFTAR PUSTAKA}

Arifin, Hardhika Wisnu. 2015. Upaya Meningkatkan Kemampuan Mengingat Urutan Kata Melalui Metode Bernyanyi. Jurnal Ilmu Pendidikan, (Online). Diperoleh 30 Januari 2017

Beaty, Jenice J. 2013. Observasi Perkembangan Anak Usia Dini. Jakarta : Kencana Prenada Media Group.

Fadlillah, M. 2012. Desain Pembelajaran PAUD. Jogjakarta:Ar-ruz Media

Irham, Muhammad \& Novan Ardy Wiyani. 2013. Psikologi Pendidikan Teori dan Aplikais dalam Proses Pembelajaran. Jogjakarta: Ar-Ruz Media

Jajha, Yudrik. 2015. Psikologi Perkembangan. Jakarta : Kencana

Latif, Mukhtar. 2013. Orientasi Pendidikan Anak Usia Dini. Jakarta : Kencana Prenada Media Group.

Muliawan, Jasa Ungguh. 2016. 45 Model Pembelajaran Spektakuler. Yogyakarta : Ar-Ruz Media.

Mutiah, Diana. 2012. Psikologi Bermain Anak Usia Dini. Jakarta : Kencana Prenada Media Group

Papalia, Diane E, dkk. 2008. Human DevelopmentPsikologi Perkembangan. Jakarta : Kencana Prenada Media Group

Pr Indonesia. 2016. Undang-Undang Republik Indonesia Nomor 20 Tahun 2003 Tentang Sistem Pendidikan Nasional. Diperoleh 20 Januari 2017. https://kelembagaan.ristekdikti.go.id

Santrock, John W. 2011. Perkembangan Anak Jilid 2. Jakarta : Erlangga.

Suryosubroto. 2009. Proses Belajar Mengajar Disekolah. Jakarta:Rineka Cipta

Walgito, Bimo. 2004. Pengantar Psikologi Umum. Yogyakarta : Andi Offset

Widyaastuti, Andini. 2016. Seabrek Kesalahan Guru Paud.Yogyakarta : Diva Press

Wijanarko, Jarot. Mendidik Anak untuk Meningkatkan Kecerdasan Emosional dan Spritual. Jakarta : Gramedia Pustaka Utama 